\title{
Mercury (Hg) and Copper (Cu) Analysis of Sea Cucumber Paracaudina australis Crackers from Kenjeran Surabaya using Atomic Absorption Spectroscopy
}

\author{
Alissa Wahidah Wulandari ${ }^{1}$, Tri Kustono Adi, Dewi Yuliani \\ Jurusan Kimia, Fakultas Sainsdan Teknologi, Universitas Islam Negeri Maulana Malik Ibrahim Malang \\ Email: t.kustonoadi@gmail.com
}

\begin{abstract}
Sea cucumber Paracaudina australis crackers is one of the sea foods processed which highly produced and consumed at Kenjeran Surabaya. The research aims to measure concentration of mercury and copper in fried and un-fried sea cucumber Paracaudina australis, Crackers collected from three supplier at Kenjeran Surabaya Using Atomic Absorption S Spectroscopy (AAS). The six sample were oxidized using oxidator agents of $\mathrm{HNO}_{3}$ $\mathrm{Pa}, \mathrm{H}_{2} \mathrm{SO}_{4} \mathrm{~Pa}, \mathrm{H}_{2} \mathrm{O}_{2} \mathrm{~Pa}$ (6:2:1) under wet-closed digestion for $\mathrm{Hg}$ analysis and wet-opened digestion for $\mathrm{Cu}$ analysis. Vapor generation Accessory (VGA-AAS) was applied for measuring $\mathrm{Hg}$ concentration while flame AAS for $\mathrm{Cu}$. The research indicated that Hg concentration in sea cucumber crackers were 0,$058 ; 0,0149 ; 0,108$ ppb (un-fried crackers) and 0,$078 ; 0,074 ; 0,061 \mathrm{ppb}$ (fried crackers) $\mathrm{Cu}$ concentration in sea cucumber crackers was measured as 2,037; 3,05; 3,16 ppm (un-fried crackers) and 1,164; 1,589; 1,924 ppm (fried crackers).
\end{abstract}

Keywords: Atomic Absorption Spectroscopy, copper (cu), mercury (Hg), sea cucumber (Paracaudina australis) crackers, wet digestion.

\begin{abstract}
ABSTRAK
Kerupuk teripang Paracaudina australis merupakan salah satu makanan olahan yang banyak diproduksi dan dikonsumsi di Kenjeran, Surabaya. Penelitian ini bertujuan untuk menentukan kadar merkuri (Hg) dan tembaga $(\mathrm{Cu})$ pada kerupuk teripang mentah dan matang menggunakan Spektroskopi Serapan Atom (SSA). Kerupuk teripang berasal dari tiga pengepul di daerah Kenjeran. Enam sampel dioksidasi menggunakan larutan pengoksidator yang terdiri dari campuran $\mathrm{HNO}_{3}, \mathrm{H}_{2} \mathrm{SO}_{4}$, dan $\mathrm{H}_{2} \mathrm{O}_{2}(6 ; 2: 1)$. Analisis $\mathrm{Hg}$ dilakukan menggunakan destruksi basah tertutup, sedangkan analisis $\mathrm{Cu}$ dilakukan dengan destruksi basah terbuka. SSA tipe VGA digunakan untuk mengukur konsentrasi Hg dan SSA tipe nyala digunakan untuk mengukur konsentrasi $\mathrm{Cu}$. Konsentrasi Hg yang diperoleh pada kerupuk teripang sebesar 0,058; 0,0149; 0,108 ppb (kerupuk mentah) dan 0,078; 0,074; 0,061 ppb (kerupuk matang) dan konsentrasi $\mathrm{Cu}$ sebesar 2,037; 3,05; 3,16 ppm (kerupuk mentah) dan 1,$164 ; 1,589 ; 1,924$ ppm (kerupuk matang).
\end{abstract}

Kata Kunci: Spektroskopi Serapan Atom (SSA), tembaga (cu), merkuri (Hg), kerupuk teripang (Paracaudina australis), destruksi basah.

\section{PENDAHULUAN}

Teripang (Holothuroidea) merupakan salah satu biota laut yang banyak dijumpai di perairan, terutama daerah tropik. Indonesia merupakan salah satu Negara pemasok teripang terbesar di pasar global karena kelimpahannya yang tinggi, termasuk Kenjeran Surabaya. Salah satu jenis teripang yang banyak dijumpai di daerah Kenjeran Surabaya adalah Paracaudina australis. Jenis teripang ini memiliki kelimpahan yang cukup tinggi dibandingkan dengan jenis teripang yang lainnya. Masyarakat sekitar daerah Kenjeran Surabaya hanya memanfaatkan teripang hanya sebatas untuk pembuatan kerupuk dan campuran sup (Winarni, 2009).

Teripang memiliki berbagai kandungan nutrisi penting bagi tubuh, seperti protein, lemak, kalsium, natrium, fosfor dan mineral (Rustam, 2006). Martoyo (1996) menjelaskan bahwa 
kandungan nutrisi teripang dalam kondisi kering terdiri dari protein $(82 \%)$, lemak $(1,7 \%)$, air $(8,9 \%)$, abu $(8,6 \%)$, dan karbohidrat $(4,8 \%)$.

Kerupuk teripang bisa menjadi berbahaya bagi tubuh apabila terkontaminasi logam berat karena sifatnya yang mudah menyerap logam melalui membran selnya pada proses bioasorpsi. Pantai Kenjeran merupakan salah satu pantai yang tercemar logam berat sehingga teripang yang sifatnya mudah menyerap logam berat maka kemungkinan besar akan ikut tercemar logam berat tersebut. Hal ini diperkuat dari penelitian yang dilakukan Balai Teknik Kesehatan Lingkungan (BTKL) Surabaya di kawasan pantai Kenjeran tahun 1997 yang menyatakan bahwa kandungan logam berat merkuri $(\mathrm{Hg})$, dan tembaga $(\mathrm{Cu})$ dalam tubuh ikan melebihi ambang batas yang ditetapkan oleh WHO dan FAO. Badan Perencanaan Pembangunan Daerah Tingkat I Jawa Timur tahun (1998) menyatakan bahwa wilayah Sukolilo Kenjeran dan sekitar kotamadya Surabaya yang menunjukkan bahwa ikan dan kerang di Surabaya mengandung $\mathrm{Hg}, \mathrm{Pb}$, dan $\mathrm{Cu}$ (Taftazani, 2007).

Selain dari bahan dasarnya, kerupuk teripang $P$. australis juga bisa terkontaminasi logam saat proses pengolahan menggunakan peralatan yang umumnya terbuat dari logam. Hal ini diperkuat oleh Darmono (1995) yang menjelaskan bahwa logam berat masuk ke dalam tubuh manusia melalui mulut berasal dari makanan akibat terkontaminasi oleh alat masak, wadah (minum/ makanan kaleng) dan juga melalui pernapasan seperti asap dari pabrik, proses industry dan buangan limbah.

Proses pengolahan kerupuk teripang seperti perebusan, penjemuran dan penggorengan juga mempengaruhi kadar logam.Connell dan Miller (1995) menyatakan bahwa perebusan akan mengakibatkan protein pengikat logam berat akan mengalami perubahan kimia dan fisika yang menyebakan logam berat terlepas dari ikatan protein sehingga akan larut dalam air. Proses penjemuran kerupuk teripang juga dapat mempengaruhi kadar $\mathrm{Hg}$ dan $\mathrm{Cu}$, karena secara alami $\mathrm{Hg}$ dan $\mathrm{Cu}$ terdapat pada udara akibat aktivitas industri-industri seperti perkapalan (Palar, 2004). Redjeki (2004) yang menyatakan bahwa proses penggorengan merupakan metode yang efektif untuk menurunkan kadar logam.

Logam berat yang dapat mencemari kerupuk teripang diantaranya adalah logam merkuri $(\mathrm{Hg})$ dan tembaga $(\mathrm{Cu}) . \mathrm{Hg}$ merupakan logam berat yang mempunyai efek toksisitas paling tinggi. Industri pengecoran logam dan beberapa industri lainnya menggunakan $\mathrm{Hg}$ sebagai bahan baku,limbahnya merupakan sumber pencemaran $\mathrm{Hg}$.Keracunan $\mathrm{Hg}$ yang akut dapat menyebabkan terjadinyakerusakan saluran pencernaan, gangguan kardiovaskuler, dan kegagalan ginjal akut (Sudarmaji, 2006).

Tembaga $(\mathrm{Cu})$ merupakan logam esensial yang diperlukan oleh tubuh meskipun dalam jumlah yang sedikit. Walaupun dibutuhkan tubuh dalam jumlah sedikit, bila kelebihan dapat mengganggu kesehatan atau mengakibatkan keracunan (Arifin,2008). Toksisitas $\mathrm{Cu}$ baru akan terlihatjika logam tersebut masuk ke dalam tubuh organisme dalam jumlah besar ataumelebihi nilai ambang batas (NAB).

Berdasarkan uraian di atas, kerupuk teripang Paracaudina australis yang barasal dari daerah Sukolilo Kenjeran diduga tercemar logam $\mathrm{Hg}$ dan $\mathrm{Cu}$. SNI telah menetapkan batas aman $\mathrm{Cu}$ dalam teripang sebesar $20 \mathrm{mg} / \mathrm{Kg}$, sedangkan batas aman $\mathrm{Hg}$ adalah $1 \mathrm{mg} / \mathrm{Kg}$. Kerupuk teripang Paracaudina australis akan dianalisis dalam 2 keadaan, yaitu mentah dan matang untuk mengetahui perbedaan kadarnya. 
Sampel teripang akan didestruksi menggunakan destruksi basah untuk memisahkan ikatan logam dan organik dalam sampel sehingga kadar logam dalam sampel bisa dianalisis. Zat pengoksidasi yang digunakan untuk analisis kadar $\mathrm{Hg}$ dan Cudalam sampel adalah $\mathrm{HNO}_{3}$ p.a, $\mathrm{H}_{2} \mathrm{SO}_{4}$ p.a, dan $\mathrm{H}_{2} \mathrm{O}_{2}$ p.a.

Metode yang digunakan dalam penelitian ini adalah metode spektroskopi serapan atom (SSA). Supriyanto (2007), yang menyatakan bahwa analisis kadar logam berat $\mathrm{Pb}, \mathrm{Cd}$, dan $\mathrm{Cu}$ pada jenis ikan tawar bisa menggunakan Spektrometri Serapan Atom (SSA) kerena mempunyai sensitifitas tinggi, mudah, murah, sederhana, cepat, dan cuplikan yang dibutuhkan sedikit.

\section{METODOLOGI PENELITIAN 1. Pengambilan Sampel}

Sampel diambil dari tiga pengolah yang ada di daerah tersebut.Setiap pengolah akan diambil kerupuk teripang $P$. australis mentah dan matang, sehingga jumlah sampel yang akan diuji sebanyak enam sampel.

\section{Preparasi Sampel}

Persiapan sampel dilakukan dengan cara kerupuk teripang P.australis mentah dioven pada suhu $100{ }^{0} \mathrm{C}$ selama 1 jam. Kemudian kerupuk teripang $P$. australis mentah dan matang dihaluskan menggunakan mortar, sehingga sampel siap untuk didestruksi.

\section{Pembuatan Kurva Standar Hg dan $\mathrm{Cu}$}

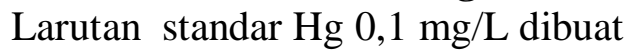
dengan cara memindahkan $10 \mathrm{~mL}$ larutan $\mathrm{Hg}\left(\mathrm{NO}_{3}\right)_{2} 1 \mathrm{mg} / \mathrm{L}$ ke dalam labu ukur $100 \mathrm{~mL}$ kemudian diencerkan dengan $\mathrm{HNO}_{3}$ sampai batas. Larutan standar $\mathrm{Hg}$ $10,00 \mu \mathrm{g} / \mathrm{L} ; 20,00 \mu \mathrm{g} / \mathrm{L} ; 30,00 \mu \mathrm{g} / \mathrm{L} ; 40,00$ $\mu \mathrm{g} / \mathrm{L}$ dan $50,00 \mu \mathrm{g} / \mathrm{L}$ dibuat dengan cara memindahkan $5 \mathrm{~mL} ; 10 \mathrm{~mL} ; 15 \mathrm{~mL} ; 20 \mathrm{~mL}$ dan $25 \mathrm{~mL}$ larutan baku $0,01 \mathrm{mg} / \mathrm{L} \mathrm{ke}$ dalam labu ukur $50 \mathrm{~mL}$ kemudian diencerkan sampai batas.
Larutan $\mathrm{Cu} 10 \mathrm{mg} / \mathrm{L}$ dibuat dengan cara memindahkan $1 \mathrm{~mL}$ larutan baku 1000 $\mathrm{mg} / \mathrm{L}$ ke dalam labu ukur $100 \mathrm{~mL}$ kemudian diencerkan dengan $\mathrm{HNO}_{3}$ sampai batas. Larutan standar $\mathrm{Cu} 0 \mathrm{mg} / \mathrm{L} ; 0,2 \mathrm{mg} / \mathrm{L}$; $0,4 \mathrm{mg} / \mathrm{L} ; 0,6 \mathrm{mg} / \mathrm{L}$ dan $0,8 \mathrm{mg} / \mathrm{L}$ dibuat dengan cara memindahkan $0 \mathrm{~mL} ; 1 \mathrm{~mL} ; 2$ $\mathrm{mL} ; 3 \mathrm{~mL}$ dan $4 \mathrm{~mL}$ larutan baku $10 \mathrm{mg} / \mathrm{L}$ ke dalam labu ukur $50 \mathrm{~mL}$ kemudian diencerkan dengan $\mathrm{HNO}_{3}$ sampai tanda batas.

Sederet larutan standar $\mathrm{Hg}$ dan $\mathrm{Cu}$ dianalisis dengan Spektrofotometri Serapan Atom (SSA) varian Spektra AA 240 pada kondisi optimum sehingga diperoleh data absorbansi masing-masing (Rohman, 2007). Nilai absorbansi yang didapatkan dibuat kurva standar $\mathrm{Hg}$ dan $\mathrm{Cu}$ dengan membandingkan nilai konsentrasi dan absorbansi.

\section{Destruksi Basah}

Sebanyak 5 gram sampel ditambahkan $30 \mathrm{~mL} \mathrm{HNO}_{3}$ dan $10 \mathrm{~mL}$ $\mathrm{H}_{2} \mathrm{SO}_{4}$. Kemudian dipanaskan dengan suhu $100{ }^{0} \mathrm{C}$ selama 3 jam menggunakan refluks untuk $\mathrm{Hg}$ danHot Plate untuk $\mathrm{Cu} . \mathrm{H}_{2} \mathrm{O}_{2}$ ditambahkan sedikit demi sedikit sampai larutan bening. Kemudian didinginkan dan disaring menggunakan kertas Whatman 42. Larutan hasil destruksi siap dianalisis menggunakan SSA. (Evans dkk, 2010; Ratmini, 2008).

\section{Pengukuran Kadar Hg dan Cu Pada Kerupuk Teripang}

Sampel untuk analisis kadar $\mathrm{Hg}$ yang telah didestruksi dimasukkan dalam botol dan siap untuk dianalisis. Sedangkan untuk sampel analisis kadar $\mathrm{Cu}$ dimasukkan kedalam labu takar $50 \mathrm{~mL}$ dan diencerkan menggunakan $\mathrm{HNO}_{3}$ 0,5 $\mathrm{M}$ sampai tanda batas. Sampel dianalisis dengan Spektrofotometri Serapan Atom (SSA) tipe VGA dengan panjang gelombang 253,7 nm untuk logam $\mathrm{Hg}$ dan tipe flame pada panjang gelombang $324,7 \mathrm{~nm}$ untuk logam $\mathrm{Cu}$, sehingga didapatkan kadar dari sampel. 


\section{Analisis Data}

Hubungan antara konsentrasi (C) dengan absorbansi (A) yang diperoleh dari data pembuatan kurva standar dapat diketahui nilai slope dan intersep. Kemudian nilai konsentrasi sampel dapat diketahui dengan memasukkan ke dalam persamaan regresi linear dengan menggunakan hukum Lambert- Beer.

Dimana :

$$
\mathrm{Y}=\mathrm{Bx}+\mathrm{A}
$$

$\mathrm{Y}=$ Absorbansi Sampel

$\mathrm{B}=$ Slope

$\mathrm{X}=$ Konsentrasi sampel

$\mathrm{A}=$ Intersep

Berdasarkan perhitungan regresi linier, maka dapat diketahui kadar logam yang sebenarnya dengan rumus umum:

Kadar $\mathrm{Hg} / \mathrm{Cu}(\mathrm{mg} / \mathrm{kg})=\frac{V x b}{W}$

Dimana: $\mathrm{V}=$ Volume akhir

$$
\begin{aligned}
\mathrm{b} & =\underset{(\mathrm{Kadar}}{\mathrm{mg} / \mathrm{L})} \\
\mathrm{W} & =\text { Berat } \text { contoh }(\mathrm{gr})
\end{aligned}
$$

\section{HASIL DAN PEMBAHASAN}

\section{Pengambilan Sampel}

Pengambilan sampel dalam penelitian ini menggunakan teknik non probability. Sampel kerupuk teripang berasal dari 3 tempat pengolah di Kenjeran Surabaya. Setiap pengolah diambil kerupuk teripang mentah dan matang, sehingga total sampel yang digunakan adalah 6 macamyang dimasukkan dalam toples kaca.Setiap toples diberi label dengan lambang A, B, C, untuk kerupuk mentah dan D, E, F untuk kerupuk matang.

\section{Preparasi Sampel}

Preparasi yang dilakukan adalah kerupuk teripang mentah dioven sampai kering untuk mengurangi kadar air dalam sampel sehingga mempermudah proses penumbukan. Selanjutnya, kerupuk ditumbuk menggunakan mortar untuk memperluas luas permukaannya sehingga proses destruksi lebih cepat. Sedangkan sampel kerupuk teripang matang langsung dilakukan penumbukan. Kerupuk teripang yang sudah ditumbuk disimpan dalam toples kaca.

\section{Pembuatan Kurva Standar}

Kurva standar merupakan standar dari suatu sampel yang digunakan sebagai acuan pengukuran kadar sampel. Kurva standar berfungsi untuk mengetahui hubungan antara konsentrasi larutan dengan nilai absorbansi sehingga dapat diketahui kadar logam dalam sampel (Underwood dan Day, 1990).

Kurva standar $\mathrm{Hg}$ yang didapat adalah sebagai berikut.

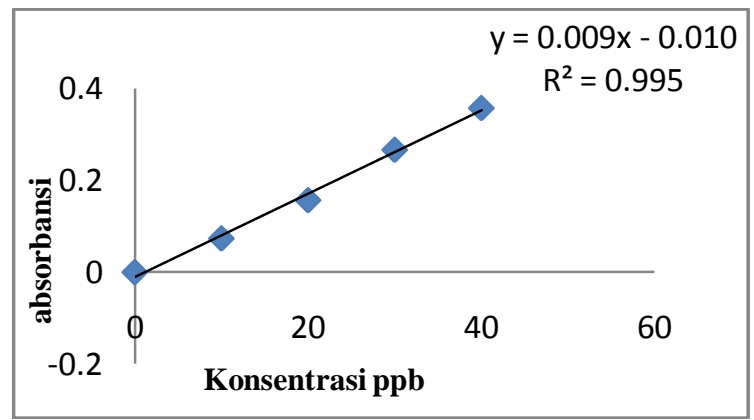

Gambar 1. Kurva standar $\mathrm{Hg}$

Persamaan linear yang didapatkan dari kurva tersebut adalah $\mathrm{y}=0,0086 \mathrm{x}-$ 0,0069. Hubungan antara konsentrasi dengan absorbansi diketahui dari nilai koefisien korelasinya (r). Hubungan konsentrasi dan absorbansi kurva diatas sangat kuat yang ditunjukkan dengan nilai $\mathrm{r}$ mendekati +1 yaitu 0,982 sehingga dapat digunakan sebagai kurva standar. Sedangkan kurva standar $\mathrm{Cu}$ adalah sebagai berikut. 


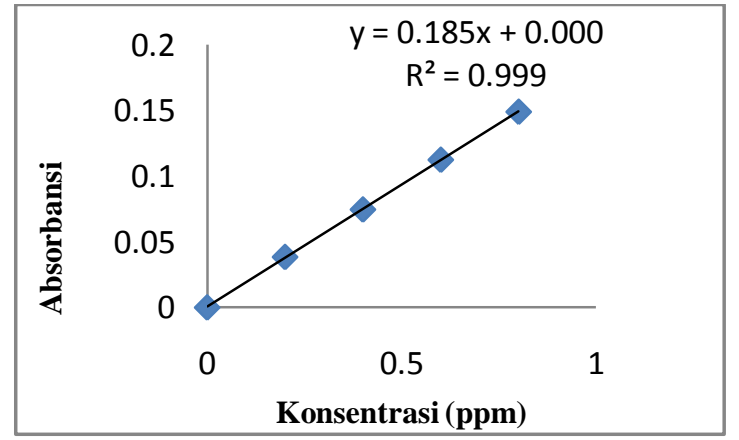

Gambar 2. Kurva standar $\mathrm{Cu}$

Grafik tersebut menunjukkan hubungan konsentrasi yang berbanding lurus dengan absorbansi dengan persamaan linear $\mathrm{y}=0,1858 \mathrm{x}+0,0006$. Hubungan liniaritas dari kurva tersebut ditunjukkan dengan nilai $r=0,9999$ sehingga dapat digunakan sebagai kurva standar.

\section{Destruksi Sampel}

Metode destruksi yang digunakan dalam penelitian ini adalah destruksi basah. Destruksi basah merupakan proses perombakan sampel menggunakan asam kuat baik tunggal maupun campuran yang berfungsi sebagai zat pengoksidasi. Menurut Sumardi (1981) metode destruksi basah memiliki beberapa keuntungan diantaranya: suhu yang digunakan rendah sehingga logam dalam sampel tidak ikut menguap dan oksidasi terjadi secara kontinyu dan cepat, serta pengerjaannya sederhana.

Proses destruksi untuk analisis $\mathrm{Hg}$ menggunakan refluks dalam lemari asapataudisebut juga dengan destruksi basah tertutup. Sedangkan $\mathrm{Cu}$ menggunakan pemanasan menggunakan hot plate atau disebut dengan destruksi basah terbuka.

Analisis logam $\mathrm{Hg}$ dan $\mathrm{Cu}$ pada penelitian ini menggunakan zat pendestruksi $\mathrm{HNO}_{3}, \mathrm{H}_{2} \mathrm{SO}_{4}$, dan $\mathrm{H}_{2} \mathrm{O}_{2}$. $\mathrm{HNO}_{3}$ berfungsi sebagai zat pengoksidasi yang akan memutus ikatan senyawa kompleks organologam. $\mathrm{H}_{2} \mathrm{SO}_{4}$ berfungsi untuk membantu mempercepat proses destruksi yang dilakukan oleh $\mathrm{HNO}_{3}$.
Proses destruksi dilakukan pemanasan pada suhu $100{ }^{\circ} \mathrm{C}$ yang berfungsi untuk mempercepat pemutusan ikatan senyawa organik dengan ikatan logam pada sampel. Pemanasan tersebut dilakukan di bawah titik didih $\mathrm{HNO}_{3}\left(121{ }^{\circ} \mathrm{C}\right)$ dan $\mathrm{H}_{2} \mathrm{SO}_{4}(290$ ${ }^{\circ} \mathrm{C}$ ), sehingga dapat mencegah $\mathrm{HNO}_{3}$ dan $\mathrm{H}_{2} \mathrm{SO}_{4}$ tidak cepat habis sebelum proses destruksi selesai (Wulandari, 2013).

Pada proses destruksi akan terjadi reaksi antara senyawa organik dengan $\mathrm{HNO}_{3}$ yang mengakibatkan ikatan unsur logam terlepas dari senyawa organik. Reaksi yang terjadi antara senyawa organik dan $\mathrm{HNO}_{3}$ (Wulandari, 2013).

$\mathrm{M}-\left(\mathrm{CH}_{2} \mathrm{O}\right)_{\mathrm{x}}+\mathrm{HNO}_{3} \rightarrow \mathrm{M}-\left(\mathrm{NO}_{3}\right) \mathrm{x}_{\text {(aq) }}+$
$\mathrm{CO}_{2(\mathrm{~g})}+\mathrm{NO}_{(\mathrm{g})}+\mathrm{H}_{2} \mathrm{O}_{(\mathrm{l})}$

Logam juga bereaksi dengan asam sulfat yang akan menghasilkan reaksi bersifat eksotermis.

$$
\begin{aligned}
& \operatorname{Logam}_{(\mathrm{s})}+4 \mathrm{H}^{+}{ }_{(\mathrm{aq})+} \mathrm{SO}_{4}{ }^{2-}{ }_{(\mathrm{aq})} \rightarrow \mathrm{Logam}^{2+}+ \\
& \mathrm{SO}_{2(\mathrm{~g})}+2 \mathrm{H}_{2} \mathrm{O}
\end{aligned}
$$

Penambahan $\mathrm{H}_{2} \mathrm{O}_{2}$ dilakukan ketika proses pemanasan selesai dengan cara meneteskan perlahan pada larutan destruksi yang masih panas. $\mathrm{H}_{2} \mathrm{O}_{2}$ berfungsiuntuk menjernihkan larutan hasil destruksi sehingga Reaksi yang terjadi adalah sebagai berikut (Wulandari, 2013).

$$
\begin{aligned}
& 2 \mathrm{H}_{2} \mathrm{O}_{2(\mathrm{l})} \rightarrow 2 \mathrm{H}_{2} \mathrm{O}_{(\mathrm{aq})}+\mathrm{O}_{2(\mathrm{~g})} \\
& 2 \mathrm{NO}_{2(\mathrm{~g})}+\mathrm{H}_{2} \mathrm{O}_{(\mathrm{aq})} \rightarrow \mathrm{HNO}_{3(\mathrm{aq})}+\mathrm{NO}_{2(\mathrm{aq})} \\
& 2 \mathrm{HNO}_{2(\mathrm{aq})} \rightarrow \mathrm{H}_{2} \mathrm{O}_{(\mathrm{aq})}+\mathrm{NO}_{2(\mathrm{~g})}+\mathrm{NO}_{(\mathrm{g})}
\end{aligned}
$$

\section{Penentuan Kadar Logam Pada Kerupuk Teripang}

Pengukuran kadar $\mathrm{Hg}$ pada penelitian ini menggunakan SSA dengan tipe VGA metode penguapan merkuri. Prinsip dasar dari analisis menggunakan VGA adalah $\mathrm{Hg}^{2+}$ dalam sampel direduksi oleh $\mathrm{SnCl}_{2}$ menjadi atom netral $\left(\mathrm{Hg}^{0}\right)$ yang berwujud 
gas dan akan menguap sebagai atom-atom bebas pada suhu normal (Dedina dan Tsalev, 1995).

Hasil pengukuran kadar $\mathrm{Hg}$ ditunjukkan pada Gambar 3.

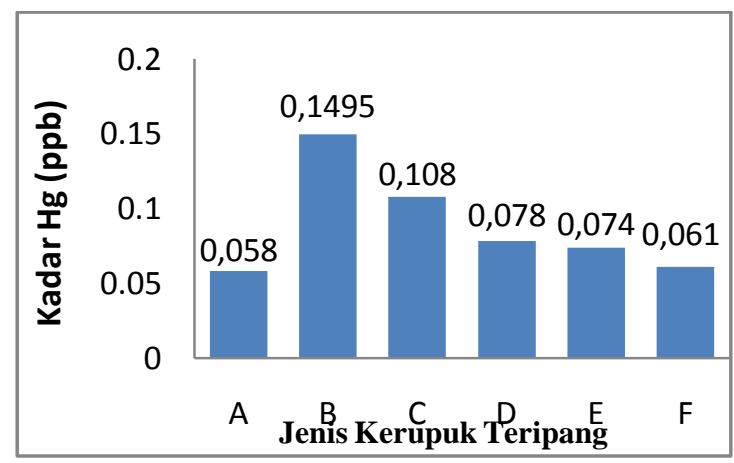

Gambar 3. Kadar Hg dalam sampel

Kadar logam $\mathrm{Hg}$ dalam kerupuk teripang matang $(\mathrm{E}$ dan $\mathrm{F})$ lebih rendah daripada kerupuk teripang mentah (B dan C). Hal ini diduga karena penggorengan menggunakan minyak mengakibatkan kadar $\mathrm{Hg}$ berkurang karena ikatan logam $\mathrm{Hg}$ diduga rusak. Effendy (2010) menyatakan bahwa logam $\mathrm{Hg}$ memiliki titik didih yang cenderung rendah karena atom $\mathrm{Hg}$ bersifat non polar yang dapat berinteraksi satu dengan yang lainnya melalui gaya London yang lemah. Oleh karena itu, dimungkinkan ikatan logam atom $\mathrm{Hg}$ dalam sampel akan terputus sehingga dimungkinkan $\mathrm{Hg}$ akan menguap.

Data hasil penelitian menunjukkan kerupuk teripang matang lebih rendah dari pada kerupuk teripang mentah. Akan tetapi, pada sampel $\mathrm{D}$ kandungan logam $\mathrm{Hg}$ setelah digoreng mengalami kenaikan. Hal ini diduga karena penggunaan minyak goreng curah yang telah mengandung logam $\mathrm{Hg}$, sehingga sampel kerupuk teripang matang lebih tinggi dari pada mentah. Hikmawati, dkk. (2006) menyatakan bahwa penggunaan minyak goreng curah yang dipakai untuk menggoreng dimungkinkan ikut memberikan kontribusi peningkatan kadar $\mathrm{Hg}$ dalam sampel ikan tongkol.
SNI (Standar Nasional Indonesia) menetapkan batas aman kadar teripang untuk dikonsumsi sebesar $1,0 \mathrm{mg} / \mathrm{Kg}$. Hasil analisis menunjukkan bahwa kadarkerupuk teripang mentah dan matang berada dibawah batas aman sehingga aman untuk dikonsumsi masyarakat.

Pengukuran kadar $\mathrm{Cu}$ dalam sampel menggunakan SSA dilakukan dengan metode nyala. Prinsip dasar tipe nyala berdasarkan pada penyerapan energi radiasi oleh atom-atom netral pada keadaan dasar, yang menyebabkan tereksitasi ke berbagai tingkat energi dengan panjang gelombang tertentu

Data hasil pengukuran kadar $\mathrm{Cu}$ pada Gambar 4.

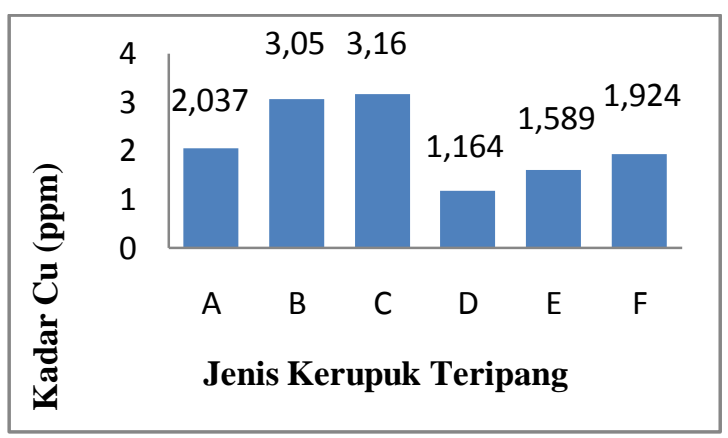

Gambar 4. Kadar Cu dalam sampel

Kadar logam $\mathrm{Cu}$ dalam kerupuk teripang matang $(\mathrm{D}, \mathrm{E}$ dan $\mathrm{F})$ lebih rendah dari pada kerupuk teripang mentah (A, B dan C). Pada kerupuk matang, logam dalam sampel terkena panas sehingga akan mengalami perubahan susunan atomnya karena logam bersifat mobil (bergerak bebas) sehingga lama-kelamaan ikatan logam antar atom akan rusak (Effendy, 2010). Menurut Listianingrum, dkk. (2008) dan Dwiloka, dkk. (2009) proses penggorengan dapat menurunkan kadar logam Co, Zn, Rb, Cr, Sc pada ayam karena ion logam terlarut bersama protein yang terdenaturasi akibat panas sehingga logam diserap oleh minyak. Logam $\mathrm{Cu}$ merupakan logam yang satu periode dengan $\mathrm{Fe}$, Co dan Zn. Urutan kekuatan ikatan logam tersebut adalah $\mathrm{Fe}<\mathrm{Co}<\mathrm{Cu}<\mathrm{Zn}$. 
Oleh karena itu, proses penggorengan pada kerupuk teripang matang juga memungkinkan dapat menurunkan kadar $\mathrm{Cu}$.

Peraturan pemerintah mengenai kadar logam tembaga yang diperbolehkan untuk dikonsumsi telah diatur melalui SNI (Standar Nasional Indonesia) yaitu sebesar $20 \mathrm{mg} / \mathrm{Kg}$.

\section{KESIMPULAN}

Kadar $\mathrm{Hg}$ pada kerupuk teripang $P$. australis mentah $(\mathrm{A}, \mathrm{B}, \mathrm{C})$ dan matang $(\mathrm{D}$, E, F) asal daerah Kenjeran Surabaya masing-masing sebesar 0,058; 0,1495; 0,108; 0,078; 0,074; dan 0,061 ppb. Kadar $\mathrm{Hg}$ pada kerupuk teripang berada di bawah batas aman SNI sebesar 1 ppm. Kadar $\mathrm{Cu}$ pada kerupuk teripang $P$. australis mentah (A, B, C) dan matang (D, E, F) asal daerah Kenjeran Surabaya masing-masing sebesar 2,$037 ; 3,05 ; 3,16 ; 1,164 ; 1,589$; dan 1,924 ppm. Kadar $\mathrm{Cu}$ pada kerupuk teripang mentahdanmatang di bawah batas aman SNI, sebesar 20 ppm.

\section{DAFTAR PUSTAKA}

Arifin, Z. 2008. Beberapa Unsur Mineral Esensial Mikro dalam Sistem Biologi dan Metode Analisisnya. Jurnal Litbang Pertanian. Vol. 27. No.3: 99-198.

Connell, D.W. dan Miller, G.J. 1995. Kimia dan Ekotoksikologi Pencemaran. Yanti Koestoer, penerjemah; Sahati, pendamping. Terjemahan dari: Chemistry and Ecotoxicology of Pollution. Jakarta: UI-Press.

Darmono. 1995. Logam dalam Sistem Biologi Makhluk Hidup. Jakarta: UI Press.

Dedina dan Tsalev. 1995. Hybride Generation Atomic Absorption Spectrometry. New York: John Wiley \& Sons.

Dwiloka, B., Pratomo, G. H., dan Atmomarsono, U. 2009. Kandungan Logam Berat Pada Usus dan Hati
Ayam Brioler yang Dipelihara dalam Kandang Litter Setelah Digoreng dan Dibakar.Prosiding Seminar Nasional AAN. Yogyakarta: Universitas Diponegoro.

Effendy. 2010. Logam, Aloi, Semikonduktor, dan Superkonduktor. Malang: Indonesian Acedemic Publishing.

Evans, S. J., Johnson., Leah R.T. 2010. Determination of Mercury in Fish Tissue, a Rapid, Automated Technique for Routine Analysis. Agilent Technologies, USA.

Hikmawati, A dan Sulistyorini, L. 2006.Perubahan Kadar Merkuri (Hg) Pada Ikan Tongkol (Euthynnus, sp) dengan Perlakuan Perendaman Larutan Jeruk Nipis dan Pemasakan. Jurnal Kesehatan Lingkungan. Vol. 3. No.1 : 67-76.

Listianingrum, Y,B., Prihatso, L., Dwiloka,B., Hintono, A., dan Atmomarsono, U. 2008. Kandungan Logam Berat pada Dada, Paha dan Hati Ayam Kampung yang Dipelihara Secara Umbaran di Daerah Sekitar Industri Candi Semarang Setelah Dimasak. Prosiding Simponium dan Pameran Teknologi Isotop dan radiasi. Yogyakarta: Universitas Diponegoro.

Martoyo J, N. Aji dan T. Miranto. 1994. Budidaya Teripang. Jakarta: Penebar Swadaya.

Palar, H. 2004.Pencemaran dan Toksikologi Logam Berat. Jakarta: Rineka Cipta.

Ratmini, N. A. 2009. Kandungan Logam Berat Timbal $(\mathrm{Pb})$, Mercuri $(\mathrm{Hg})$ dan Kadmium (Cd) Pada Daging Ikan Sapu-Sapu (Hyposarcus pardalis) di Sungai Ciliwung Stasiun Srengseng, Condet Dan Maggarai. Jurnal VIS VITALIS. Vol. 2. No.1: 1-7. 
Redjeki, S. 2004. Pengaruh Pengolahan Terhadap Kadar $\mathrm{Hg}$ pada Ikan Keting. Tesis. Surabaya: Universitas Air Langga.

Savitri, P.O., Indah, R. dan Rachmatilah, S.S. 2012. Kajian Kandungan Logam Berat pada Ikan Air Tawar di Pasar Tradisional dan Pasar Swalayan kota Bandung. Program Studi Teknik lingkungan Institut Teknologi Bandung, Bandung.

Shihab, Q. 2002. Tafsir Al-Mishbah : Pesan, Kesan, dan Keserasian AlQur'an. Jakarta : Lentera Hati.Standar Nasional Indonesia (SNI). 2009. Batas Maksimum Cemaran Logam Berat dalam Pangan. SNI 7387.

Sudarmaji, J. M, dan Corie I.P. 2006. Toksikologi Logam Berat B3 dan Dampaknya Terhadap Kesehatan. Kesehatan Lingkungan

Sumardi. 1981. Metode Destruksi Contoh Secara Kering Dalam Analisa Unsur-Unsur $\mathrm{Fe}-\mathrm{Cu}-\mathrm{Mn}$ dan $\mathrm{Zn}$ Dalam Contoh-Contoh Biologis. Proseding Seminar Nasional Metode Analisis. Lembaga Kimia Nasional. Jakarta: LIPI.
Supriyanto, C. Samin. dan Z. Kamal. 2007. Analisis Cemaran Logam Berat $\mathrm{Pb}$, $\mathrm{Cu}$ dan $\mathrm{Cd}$ pada Ikan Air Tawar dengan Metode Spektrofotometri Nyala Serapan Atom (SSA). Seminar Nasional III SDM Teknologi Nuklir. Yogyakarta, 2122 Nopember 2007, Yogyakata.

Taftazani, A. 2007. Evaluasi Sebaran Logam $\mathrm{Hg}, \mathrm{Cd}, \mathrm{Cr}$, dan Co dalam Cuplikan Air, Sedimen dan Enceng Gondok di Lokasi Perairan Surabaya III. Jurnal Ganendra. Vol. 4. No. 2: 28-37.

Underwood, A. L. dan Day R.A. 2001.Analisa Kimia Kualitatif edisi Ke Enam. Jakarta: Erlangga.

Winarni, D., Affandi, M., Masithah, E.D. dan Darmayanti, H. 2012.Tahap Kematangan Gonad Teripang Paracaudina australis Pada Bulan Februari, Maret dan April 2012. Jurnal Oseana.

Wulandari, E, A. dan Suksesi. 2013. Preparasi Penentuan Kadar Logam $\mathrm{Pb}, \mathrm{Cd}$, dan $\mathrm{Cu}$ dalam Nugget Ayam Rumput Laut Merah (Eucheuma cottoni). Jurnal Sains dan Seni Pomits.Vol. 2.No.2 : 15-17 